The final publication is available at IOS Press through http://dx.doi.org/10.3233/EFI-190363

\title{
Building a trauma-informed community of practice
}

Authors: Nicola Laurent (corresponding author) and Michaela Hart

Affiliations: Nicola Laurent, Find \& Connect web resource, Faculty of Arts, University of Melbourne, Victoria, Australia.

Michaela Hart, Records Management Unit, Department of Health and Human Services, Victoria, Australia.

Correspondence: Nicola Laurent, Faculty of Arts, University of Melbourne, Parkville, Victoria 3010, Australia. Tel.: +61 383442762 Email: nicola.laurent@unimelb.edu.au

Abstract: This paper calls for a global community of practice to support people to enact trauma-informed practice in the archival profession. Building on the literature around archives and affect, decolonising spaces, and centring communities, it proposes traumainformed practice is implemented in archives, and a community of practice be established to support those doing the work. It recognises the emotional labour of many in the archival field, and furthers conversations held at Archival Education Research Institute 2019 where the value of a community of practice was evidenced. The community of practice would bring together communities, academics, researchers, practitioners, volunteers, users, donors, and anyone with an interest in improving archival theory, education and practice to support trauma-informed approaches in archives, and support those undertaking the work. It ends with a call for co-creators of a trauma-informed community of practice.

Keywords: Trauma-informed practice, Trauma-informed archival practice, Archives, Community of practice, Emotional Labour. 
We need a global community of practice to support people enacting trauma-informed practice within the archival profession.

In this paper, "trauma-informed" is used to broadly reflect work that, whether named as such or not, is underpinned by a strengths-based framework founded on the five principles of choice, collaboration, safety, trust and transparency, and empowerment (Hopper, Bassuk, \& Olivet, 2009). Taking a trauma-informed approach focuses on the way we treat other people (Blue Knot Foundation, 2019), and involves recognising trauma and its effects as pervasive, undertaking work with the intention to do no harm, supporting staff, and creating a safe environment for everyone involved in an interaction.

The community of practice we are proposing brings together academics, practitioners and other interested parties, to share resources, skills, learnings and ideas to improve the implementation of trauma-informed approaches and ensure everyone is supported while doing this often difficult and challenging work.

Within an archival context, trauma-informed services should provide the best experience possible to everyone who interacts with the archives. Being trauma-informed impacts the way we do our work, rather than what we do. Introducing the five trauma-informed principles makes the archives a safer and more empowering place for all, reducing the risk of people being triggered by potentially traumatic records, including protecting archivists from the effects of vicarious or secondary trauma (Sloan, Vanderfluit \& Douglas, 2016).

Our work in this space sits alongside critical work in decolonising spaces and the centring of community partners, where the focus is on shifting power from the archive and the archivist to community (McKemmish et al., 2019; Thorpe, 2019; Luker, 2017; Caswell \& Cifor, 2016; Henningham, Evans \& Morgan, 2017; McKemmish, Faulkhead \& Russell, 2011). Using social constructivist theory to ground our thinking, we believe that it is our relationships and 
interactions with others that shape who we are, what we know and how we think (Charmaz, 2014). We acknowledge that our actions as archivists are anything but neutral, that records can traumatise, and the construct of the archive itself is designed to maintain power and control.

Our backgrounds are important for understanding why we can and should argue for traumainformed practice in archives, and the need to support this implementation by building a community of practice. We want to make our roles visible throughout this position paper, being transparent in acknowledging the privilege we have as white middle-class women to have the space and capacity to have these conversations. We respect and value those with positionalities other than our own and acknowledge their significant and ongoing contributions to the archival profession.

We both come to this with a background in the Australian out-of-home care records sector, working with Care Leavers, Forgotten Australians and others who have experienced the effects of institutional or out-of-home care as children. We presented at the 2017 Australian Society of Archivists' conference on vicarious trauma and emotional labour because we felt it was a timely and necessary conversation to be having in our profession. In Australia, the Royal Commission into Institutional Responses to Child Sexual Abuse was coming to a close and many archivists had spent the previous five years working in response to the Commission, often alone and unsupported (Hart \& Laurent, 2017). Still, we were unsure about how the topic would be received, and felt we were potentially breaching a professional norm that requires us to be "impartial" and impersonal. But from our first collaboration, we have seen firsthand the value of providing a space and place for people to share and learn from each other's experiences.

We started this dialogue around vicarious trauma within the Australian archives community to allow for a co-creation of understanding, and the untangling of the nuances and 
messiness that can occur when you step outside safer theoretical spaces. That one 90minute discussion started conversations that have had ongoing benefits including known improvements in practice and a more open dialogue that allows people to ask for support. It has also led to the creation of practical resources including an online course called "A Trauma-Informed Approach to Managing Archives", launched in March 2020 (Australian Society of Archivists, 2020). But we have also seen firsthand the affective impact traumatic records can have on those who interact with them, and equally the affective power in the absence of records.

Affect and archives has been a significant topic of discussion within the literature in recent years (Gilliland, 2014; Russell, 2018; Wilson \& Golding, 2016; Cifor \& Gilliland, 2016; Caswell \& Cifor, 2016; Sloan, Vanderfluit \& Douglas, 2019), and as Douglas and Mills (2018, p.261) state, "while affect is not strictly synonymous with emotion, the emotional dimension of recordkeeping is highlighted in many of the recent articles on archives and affect; a particular strain of emphasis is on the intensely personal emotions elicited in confrontation with—or, equally, in the absence of access to-organizational records". Within the archival discourse, affect theory has been acknowledged as a way to recognise, make visible and engage with social justice frameworks to create a more just archival profession (Cifor, 2016). While the literature around affect theory and archives is emerging, this is an important theoretical avenue to explore alongside the practical approach of trauma-informed practice in archives.

The role of affective responsibilities within the archival profession was introduced by Caswell and Cifor (2016, p.24), who argued for archivists to centre radical empathy through the relationships "between archivists and records creators, between archivists and records subjects, between archivists and records users, and between archivists and larger communities". These responsibilities were further extrapolated at the 2017 Society of 
American Archivists conference with the addition of a fifth relationship proposed, archivist to archivist (Arroyo-Ramirez, 2017; Wooten, 2018). We argue that using a trauma-informed approach in archival work is a practical way to enact radical empathy, recognising the affective responsibilities of archivists, and the affective potential of records and archives, even in their silences (Laurent \& Hart, 2018; Laurent \& Wright, 2020).

Having experienced the benefits of inviting academics into practitioner spaces, and viceversa, we seek to strengthen these relationships and shape future collaborations in a more structured and meaningful way. We are aware of isolated pockets of work by groups and individuals around the world taking steps towards trauma-informed archival practice and including the topic within programmes of research. We believe there is also need for evidence to advocate for change within organisations, to share learnings, and to support each other.

We also recognise the emotional labour occurring within the archival profession, and of the effect it can have on ourselves and our colleagues. While this is gaining increasing acknowledgement within the literature (for example, Powell et al., 2018; Thorpe, 2019; St Onge, 2016), it is not always recognised in workplaces and translated into a change within practice. This is a particularly important topic to engage with as we look to diversify the archival profession. Being trauma-informed requires the archives to be a safe and empowering place for everyone, including staff, and it is difficult to encourage diversity within the archival profession, if the places they must work are not safe. As Thorpe (2019) discusses, "working in a culturally safe environment has a real impact on people; however, there is a lack of attention from institutions in acknowledging and taking action to improve these conditions". By having a supportive community of practice in place, we can support the personal growth and critical thinking trauma-informed archival work necessitates while restructuring the profession. 
We believe that a global community of practice is needed for trauma-informed approaches to sufficiently infiltrate practice, impact research agendas, and bring the people, resources and skills together to make long-term, ongoing effective change within the archival profession. The community of practice would provide an opportunity to minimise the gap between archival theory and practice, maximising the efforts of those already working to make the archives a safe and empowering place for all who use them and all who are currently excluded from them.

We see building an effective community of practice as one way to strengthen ongoing research programmes, ensuring that academic outputs support practice and listen to the valuable contributions of practitioners and the wider community. We want this community of practice to bring together communities, academics, researchers, practitioners, volunteers, users, donors, and anyone with an interest in improving archival theory, education and practice to support trauma-informed approaches in archives.

At the Archival Education and Research Institute in 2019, the potential value of a community of practice was evidenced. Our session brought together four presentations, from four countries, focusing on various aspects of trauma in archives (Duff, Aton \& Shields, 2019; Hart \& Laurent, 2019; Roeschley, 2019; Sexton, 2019). These conversations, alongside others during the week, such as Jennifer Douglas et al's (2019) discussion of grief work and archives, reinforced that the profession is moving towards a common understanding of the role of affect and archival practice. It also revealed areas where further discussion, and more research is needed, particularly around nomenclature - the language used within all four presentations differed, and we continue to question if the use of the word "trauma" is the right word to use within the archival community (Laurent, 2019; Laurent \& Wright, 2020). There was real power in the panel of practitioners and academics - Wendy Duff, Henria Aton, Anna Sexton, Ana Roeschley and ourselves - acknowledging each other's work and 
holding space for each other to have these difficult conversations. We want to see more of this.

Emboldened by our own experiences and supported by this growing community and literature, we have been encouraged to continue to have these conversations, and push for better resources and support. As practitioners, we have carried on this work alongside our core roles but this has not been without cost, particularly in additional emotional labour. As trauma-informed practice becomes a part of archival curricula, as is our hope, we foresee a flow on to work practices, with necessary adjustments made within institutions to meet the expectations of new practitioners entering the workforce. A community of practice is a first step in bringing together the groups and individuals who are working around the world to make archives safer and more welcoming spaces for archivists, volunteers, donors and users alike. We invite anyone who would be interested to help co-create this community to get in touch with us.

\section{Reference List}

Arroyo-Ramirez, E., Brown, M., Handel, D., Mattson, R., Mecagni, G., Smith, H., \& Wooten, K. (2017, July). Radical Empathy in Archival Practice. Paper presented at the Society of American Archivists conference, Portland, OR. Retrieved from https://archives2017.sched.com/event/ABGy/301-radical-empathy-in-archival-practice Australian Society of Archivists. (2020). A Trauma-Informed Approach to Managing Archives. Retrieved from https://www.archivists.org.au/events/event/a-trauma-informedapproach-to-managing-archives 
Blue Knot Foundation. (2019). Trauma-informed Care and Practice. Retrieved from

https://www.blueknot.org.au/Workers-Practitioners/For-Health-Professionals/Resources-for-

$\underline{\text { Health-Professionals/Trauma-Informed-Care-and-practice }}$

Caswell, M., \& Cifor, M. (2016). From Human Rights to Feminist Ethics: Radical Empathy in the Archives. Archivaria, 81, 23-43. Retrieved from

https://archivaria.ca/index.php/archivaria/article/view/13557

Charmaz, K. (2014). Constructing grounded theory (2nd ed.). Los Angeles, CA: Sage.

Cifor, M. (2016). Affecting relations: introducing affect theory to archival discourse. Archival Science. 16(1), 7-31. doi:10.1007/s10502-015-9261-5

Cifor, M., \& Gilliland, A. (2016). Affect and the archive, archives and their affects: an introduction to the special issue. Archival Science. 16(1), 1-6. doi:10.1007/s10502-015-92633

Douglas, J., \& Mills, A. (2018). From the sidelines to the center: reconsidering the potential of the personal in archives. Archival Science. 18(3), 257-277. doi:10.1007/s10502-018-92956

Douglas, J., Alisauskus, A., Larson, E., \& Lee, T. (2019, July). Continuing Presence: Grief Work, Records Work and Acts of Love. Paper presented at Archival Education and Research Institute, Liverpool.

Duff, W., Aton., H \& Shields., M. (2019, July). Challenges Faced by Archivists Working with Sensitive Records. Paper presented at Archival Education and Research Institute, Liverpool. 
Gilliland, A. (2014). Moving past: probing the agency and affect of recordkeeping in individual and community lives in post-conflict Croatia. Archival Science. 14(3-4), 249-274. doi: 10.1007/s10502-014-9231-3

Hart, M., \& Laurent, N. (2019, July). Building a Trauma Informed Community of Practice. Paper presented at Archival Education and Research Institute, Liverpool.

Hart, M., \& Laurent, N. (2017, September) Session 4B - Addressing Separation Loss \& Trauma [Video file]. Paper presented at the Australian Society of Archivists annual conference, Melbourne, Vic. Retrieved from https://youtu.be/RWZNGrxGs44

Henningham, N., Evans, J., Morgan, M. (2017). The Australian Women's Archives Project: Creating and Co-curating Community Feminist Archives in a Post-Custodial Age. Australian Feminist Studies, 32(91-92), 91-107. doi:10.1080/08164649.2017.1357015

Hopper, E. K., Bassuk, E. L., \& Olivet, J. (2009). Shelter from the Storm: Trauma-Informed Care in Homelessness Services Settings. The Open Health Services and Policy Journal, 2, 131-151. Retrieved from http://www.traumacenter.org/products/pdf files/shelter from storm.pdf Laurent, N. (2019, October). Designing a trauma-informed archive (\& archivist). Paper presented at the Australian Society of Archivists, Archives and Records Association of New Zealand Te Huinga Mahara, the International Council on Archives and the Pacific Regional Branch International Council on Archives joint international conference, Adelaide.

Laurent, N., \& Hart, M. (2018). Emotional Labour and Archival Practice - Reflection. Journal for the Society of North Carolina Archivists. 15(2018), 13-22. Retrieved from http://www.ncarchivists.org/wp-content/uploads/2019/02/jsnca vol15 laurent-hart-1.pdf 
Laurent, N., \& Wright, K. (2020). A trauma-informed approach to managing archives: a new online course. Archives and Manuscripts. 48(1), 80-87.

doi:10.1080/01576895.2019.1705170

Luker, T. (2017). Decolonising Archives: Indigenous Challenges to Record Keeping in 'Reconciling' Settler Colonial States. Australian Feminist Studies, 32(91-92), 108-125. doi:10.1080/08164649.2017.1357011

McKemmish, S., Bone, J., Evans, J., Golding, F., Lewis, A., Rolan, G., Thorpe, K., \& Wilson, J. (2019). Decolonizing recordkeeping and archival praxis in childhood out-of-home Care and indigenous archival collections. Archival Science, 1-29. doi:10.1007/s10502-019-09321Z

McKemmish, S., Faulkhead. S., \& Russell, L. (2011). Distrust in the archive: reconciling records. Archival Science, 11(3-4), 211-239. doi:10.1007/s10502-011-9153-2

Powell, C., Smith, H., Murrain, S., \& Hearn, S. (2018). This [Black] Woman's Work: Exploring Archival Projects that Embrace the Identity of the Memory Worker. KULA: knowledge creation, dissemination, and preservation studies, 2(1). Retrieved from https://kula.uvic.ca/article/10.5334/kula.25/.

Roeschley, A. (2019, July). Campus Archives in the Shadow of Campus Sexual Assault. Paper presented at Archival Education and Research Institute, Liverpool.

Russell, L. (2018). Affect in the archive: trauma, grief, delight and texts. Some personal reflections. Archives and Manuscripts. 46(2), 200-207. doi:10.1080/01576895.2018.1458324 
Sexton, A. (2019, July). Working with traumatic records: how should we train, prepare and support record-keepers?. Paper presented at Archival Education and Research Institute, Liverpool.

Sloan, K., Vanderfluit, J., \& Douglas, J. (2019). Not 'Just My Problem to Handle': Emerging Themes on Secondary Trauma and Archivists. Journal of Contemporary Archival Studies. 6(20), 1-24. Retrieved from https://elischolar.library.yale.edu/jcas/vol6/iss1/20/

St. Onge, A. (2016, June). Already Enough Ghosts:The Invisibility of Emotional Labour in Archives. Paper presented at the Association of Canadian Archivists annual conference, Montreal. Retrieved from http://hdl.handle.net/10315/31367

Thorpe, K. (2019). Transforming Praxis - Building Spaces for Indigenous Self-Determination in Libraries and Archives. In the Library With the Lead Pipe, 2019. Retrieved from http://www.inthelibrarywiththeleadpipe.org/2019/transformative-praxis/

Wilson, J., \& Golding, F. (2016). Latent scrutiny: personal archives as perpetual mementos of the official gaze. Archival Science. 16(1), 93-109. doi:10.1007/s10502-015-9255-3

Wooten, K. (2018). Radical Empathy in Archival Practice zine. Retrieved from https://radicalempathy.tumblr.com/post/172280638489/we-updated-our-mini-zine-for-thenew-england 


\section{University Library}

\section{- M M I E E R VA A gateway to Melbourne's research publications}

Minerva Access is the Institutional Repository of The University of Melbourne

Author/s:

Laurent, N;Hart, M

Title:

Building a trauma-informed community of practice

Date:

2020

Citation:

Laurent, N. \& Hart, M. (2020). Building a trauma-informed community of practice. Education for Information, 37 (1), pp.1-6. https://doi.org/10.3233/efi-190363.

Persistent Link:

http://hdl.handle.net/11343/265868 